\title{
Creativity techniques applied to improve product characteristics: study of handicraft products
}

\author{
Edicleide da Silva Marinho, Mario Orestes Aguirre González, Amanda Freire, Marcela Squires Galvão Fernandes, \\ Ana Cláudia Costa de Araújo \\ Universidade Federal do Rio Grande do Norte \\ e-mails: edicleidesm@gmail.com; mario@ct.ufrn.br; a._freire@hotmail.com; marcela_squires@yahoo.com.br; anaclaudiacostaaraujo@gmail.com
}

\begin{abstract}
Creativity, considered a skill that provides innovation, either in the creation of new products or their improvement, needs to be exercised in order to be. Thus, creativity techniques are being increasingly studied; however there are still few empirical studies on the subject. This article aims to evaluate the application of a creativity technique in two communities that produce handicraft products in the state of Rio Grande do Norte. Through a literature review, we found a total of 74 creativity techniques from which we chose the SCAMPER technique. It provides improved products, is easy to apply, and is suitable for target audience with low level of education. The results demonstrated that the technique presented satisfactory performance on improvement of product characteristics. However, the participant's creative knowledge must be taken into account before its application.
\end{abstract}

Keywords: creativity techniques, product development, SCAMPER, creative potential.

\section{Introduction}

A production system is a way of organizing work, the human and material resources for processing into products that meet a demand in the market. In Old Age and in the Middle Ages the work and the production were primarily craft, because the responsibility for product design, production process and selection of the materials were the artisans themselves.

The artisanal production system is characterized as being of low complexity when compared to the industrial sector, as well as in other sectors, the development of new products has become necessary in this sector, due to changes in market demand. If, in the past, artisanal products had a long life cycle, today, tends to be increasingly short, influenced by cultural and social changes. In this new scenario, the term creativity is presented as an essential factor that helps in generating ideas to create new products (PAGE; SCHIRR, 2008; GONZÁLEZ et al., 2014), create new processes (CHESBROUGH, 2011), improve the characteristics of current products (AMARAL; ROZENFELD, 2001; GONZÁLEZ; TOLEDO, 2012).

According to Souza and Soares (2007), to enhance creative skills, provided one is able to deal with uncertainties and is able to generate new forms of adequacies to new social and natural demands, causing producers of knowledge to become problem solvers.

For this purpose, several techniques are found in the literature for transcribing and improvement in creativity and innovation. Thus, the development of techniques that seek to increase the creative potential and the focus on an innovation becomes relevant in the craft sector. This article aims to evaluate the application of a creativity technique in two artisans' communities.

The article is divided into 7 parts, with the first introduction. The second and third topics discuss the theoretical framework on creativity and creativity techniques topics. Thereafter, research method was presented and the fifth part considers the case study, covering the application of intervention by SCAMPER technique. The analysis of the interventions is presented in sixth part. The final considerations make up the seventh part, followed by the references.

\section{Creativity}

Creativity is seen as a skill that can be developed from the environment to which the individual belongs (VAN EIJNATTEN; SIMONSE, 1999; OSTROWER, 1999; ROFFE, 1999; MARTINS; MARTINS, 2002; BRUNO-FARIA, 2007; SOUZA; SOARES, 2007; BRUNO-FARIA et al., 2008; SILVA et al., 2009; ISAKSEN; EKVALL, 2010). Each individual is born with a potential that can be developed over time or not (BERGER et al., 1995; BRENNAN; DOOLEY, 2004).

Enhancing the innovative capacity by generation of ideas, creativity is becoming an essential factor for the development of new products (NAKAKOJI et al., 2000; FAMILY, 2003; 
FISCHER et al., 2005; BISSOLA; IMPERATORI, 2011). Alencar (1996) emphasizes the need for emergency of creativity within organizations, due to the frenzied pace of scientific and technological advances that have made knowledge become obsolete in a short period of time, thus requiring a capacity for continuous and lifelong learning (GURTEEN, 1998; SOUZA; SOARES, 2007; SILVA et al., 2009).

\section{Creativity techniques}

According to Runco (2007) and Baccarelli (1999) to create belongs to human nature, but the creative talent is something that is based largely on educational work, which requires the acquisition of knowledge, skills and personal qualities.

Creativity can be enhanced with the use of techniques which encourage the use of abstraction, association and escape reality in order to contribute to greater generation of ideas and problem solutions. Specific methods whose success is related to a previous study on the population for the implementation of the method, as regards the characteristics of the individual, the environment in which they are placed, aspects of the organization involved, in addition to having an opening strategy, because it is something new.

Based on the results obtained by Smith (1998), the following aspects must be observed before application of any technique or method for directing creativity towards innovation:

- Strategically planning the form of application of the technique/method;

- Planning persuasion techniques against possible barriers;

- Familiarity with the characteristics of the groups with which you are working with;

- Use technique/method that is quick and convenient;

- To have flexibility; and

- Try to convince the leadership to participate.

The facilitator of the technique has very important role in the implementation of the same, because it depends on the understanding of the procedure on the part of the participants. For the technique to be applied properly, it is necessary that individuals believe in the method in order to interact in the best possible way, and this is also due to the facilitator.

Several techniques are found in the literature, with different objectives, methods of application and complexity. In Table 1 the distribution of techniques based on their objectives, which can be (1) problem solving; (2) pool resources for a new idea;

Table 1. Classification of techniques by objective.

\begin{tabular}{|c|c|}
\hline PURPOSE & TECHNIQUES \\
\hline Deepening view of the problem & $\begin{array}{l}\text { Dimensional analysis, Analogies, Assumption Smashing, Assumption Surfacing, Chunking, Criteria } \\
\text { for the idea - finding the potential, Definitions from other people, Do nothing, Border examination, } \\
\text { Fan concept, Paraphrasing keywords, Why? Why? Why?, Who are you?, Redaction, Multiple reset }\end{array}$ \\
\hline $\begin{array}{l}\text { Deepening view of the problem and } \\
\text { Pool Resources for a new idea }\end{array}$ & 5W2H, Dialectic approach \\
\hline $\begin{array}{l}\text { Deepening view of the problem and } \\
\text { problem solving }\end{array}$ & Strategic management process \\
\hline Evaluate ideias & Paired comparison, Checklist comparison, NAF, PIPS, Bullet proof, Comparison table \\
\hline Developing pre-defined idea & Scheduling \\
\hline Generate diverse ideas & Disney’s creativity strategy, Successive element integration, THRIL \\
\hline $\begin{array}{l}\text { Develop pre-defined idea / improve } \\
\text { products }\end{array}$ & $\begin{array}{l}\text { Bodystorming, Morphological forced connections, Listing, Random words / figures, Serial questioning } \\
\text { - 'Applied imagination', SCAMPER, SCAMPERR, Super group }\end{array}$ \\
\hline $\begin{array}{l}\text { Generate ideas to create/improve } \\
\text { products and Problem solving }\end{array}$ & Lotus blossom, , Lateral thinking \\
\hline $\begin{array}{l}\text { Identify areas / issues where to } \\
\text { apply innovation }\end{array}$ & Gap analysis, Bug list \\
\hline Pool resources for a new idea & $\begin{array}{l}\text { Backwards forwards planning, Brainstorming, Visual Brainstorming, Brainwriting, Ideatoons, } \\
\text { Speaking pictures, Shooting method, In the Empire of senses, Metaphorical thinking, Discontinuity } \\
\text { principle, Provocation, Story board, Super heroes, Synectics, Work with dreams and images }\end{array}$ \\
\hline Solving problems & $\begin{array}{l}\text { AIDA, Stimulus analysis, Imaginary Brainstorming. Do it, Exaggeration, Making questions, Mental } \\
\text { mapping, New view, Unified structured inventive thinking, Fuzzy thinking, Unconscious problem } \\
\text { solving, Problem reversal, Six thinking hats, TILMAG - Transformation of ideal solution elements } \\
\text { with a common associations matrix, TRIZ }\end{array}$ \\
\hline $\begin{array}{l}\text { Solving problem and Generate } \\
\text { diverse ideas }\end{array}$ & Productive thinking model \\
\hline $\begin{array}{l}\text { Solving problem and Pool resources } \\
\text { for a new idea }\end{array}$ & Snowball \\
\hline
\end{tabular}

Source: Elaborated by the authors. 
(3) generate ideas to create / improve product; (4) deepening view of the problem; (5) evaluate ideas; (6) identify areas / issues where to apply innovation; (7) generate different ideas; (8) developing pre-defined idea.

\section{Method of research}

The present research can be characterized based on its goal as exploratory (MIGUEL, 2010), as to the scientific approach as qualitative (CRESWELL, 2010), and as a multiple case study on the technical procedure used (YIN, 001). Seven phases were defined for its development.

In the first phase, a field survey was carried out in order to know the reality of the two artisans' communities. The tools used to obtain the data at this stage can be said to be essentially conversational action, recording of facts and images. It was observed that, in this first instance, activity stimulating the improvement of existing products in communities was not in existent.

In the second phase, we performed a literature search, to find creative techniques to help the artisans in developing creative potential for the purpose of improving the features and functionality of the existing products. To list the existing techniques, we used Google search engine on the internet and the CAPES' Journal Portal (Coordenação de Aperfeiçoamento de Pessoal de Nível Superior). For this search, the key words were used "técnicas de criatividade", "técnicas para gerar ideias", "métodos de geração de ideias" and their translations "creativity techniques", "techniques of generating ideas", "methods of generating ideas". We found a total of 162 articles.

In the third phase, an analysis was made of articles in order to identify its contributions to research. This check was carried out by reading the summary and a quick reading of the articles altogether. After the diagnosis of detachment of these publications with the content to be investigated, only one article was of creativity techniques.

In the fourth phase, to find the references, quotes and sites, we used the Google search engine. The research led to the two sites where all techniques were obtained: Creativity Web and Mycoted. In total were found 74 techniques.

The choice of the technique implemented in the communities - SCAMPER - took into account the research objective - to improve the features and functionality of existing products -; the simplicity of application, since the level of education of the artisans, who are the research target, is not advanced; and also to ensure that they can be applied together.

In the fifth phase, a dynamic of application of the chosen technique was developed, which consists of three stages: planning, execution and analysis. Each step has sub steps that vary with the dynamics of the objective.

The first step corresponds to the planning of the dynamics, spanning four sub stages: selection of dynamic facilitators, their assistants, necessary equipment for applying it and discuss its implementation.

The second stage has four sub-steps. Primarily, choose along with the participants, products with lower demand, which will be focus of improvement. After the auxiliary table is constructed (Table 2) according to the skills of the artisans. The auxiliary table will list all the variables of craft production of the association, that is, everything that can be changed. Thus, each column of the table is a variable, and the lines all the possibilities for each variable.

In the third sub step, filling of the SCAMPER table takes place (Table 3) with the suggestions given by the artisans and with the help of auxiliary table. The SCAMPER table is quite simple to fill. In the columns chosen products to be improved on and in rows have been stages of SCAMPER, each represents a change in different aspects of the product. Replace represents changing aspect(s) of the other(s); Combine is add products and components or aspects that will add its value to the product under study; Adapting means changing the function of the product without much change of its characteristics; Modify includes change any aspect of the product, like to vary the characteristics of the product; Put into use, that give other utilities to the product without it fails to fulfill its original purpose; Eliminate implies exclusion of features; and reinventing considers to completely change the product.

However, it is not necessary to fill all the spaces available, as changes are made in accordance with the characteristics of the product and flexibility of production.

The last step is done under the summary of all the options found in the SCAMPER table. The analysis phase of the dynamics is responsible for analyzing the results of the previous steps, as well as the feasibility of implementation of the proposed improvements.

Table 2. Example of auxiliary table $(\mathrm{P}=$ Possibility $\mathrm{V}=$ Variable $)$.

\begin{tabular}{|l|l|l|l|c|c|}
\hline Variable 1 & Variable 2 & Variable 3 & Variable 4 & Variable ... & Variable n \\
\hline P1 for V1 & P1 for V2 & P1 for/ V1 & P1 for V4 & P1 for ... & P1 for Vn \\
\hline P2 for V1 & P2 for V2 & P2 for V1 & P2 for V4 & P2 for ... & P2 for Vn \\
\hline P3 for V1 & P3 for V2 & P3 for V3 & P3 for V4 & P3 for ... & P3 for Vn \\
\hline P...for V1 & P...for V2 & P...for V3 & P...for V4 & P... for ... & P... for Vn \\
\hline Pn for V1 & Pn for V2 & Pn for V3 & Pn for V4 & Pn for ... & Pn for Vn \\
\hline
\end{tabular}

Source: Elaborated by the authors. 
In phase 6 of the research method, interventions in communities were carried out through application of the dynamics in a period of three months. Initially the group responsible for the implementation of dynamic was presented, as well as the artisans. After this step, the dynamic was performed.

In the seventh stage, we analyzed the results obtained with the purpose of identifying positive and negative points of the technique used, with a view to subsequently propose improvements.

\section{Case studies}

\subsection{Group of artisans from Massaranduba}

Founded in October 20, 2003, Artmar (Association of artisans from Massaranduba) was meant to compensate for the idleness of community women, doing embroidery. However, due to insufficient conditions to market their products they sought aid in SEBRAE, which conducted research on the community and suggested that they worked with carnauba fiber (Figure 1), an abundant raw material in the region.

The group currently consists of 10 members and the association is made through the registration of members in

Table 3. Example of SCAMPER table.

\begin{tabular}{|l|l|l|l|l|}
\hline \multicolumn{1}{|c|}{ Stage } & Product 1 & Product 2 & Product ... & Product n \\
\hline S - Sustitute & & & & \\
\hline C-Combine & & & & \\
\hline A-Adapt & & & & \\
\hline M-Modify & & & & \\
\hline P- Purpose & & & & \\
\hline E- Eliminate & & & & \\
\hline R- Reverse & & & & \\
\hline
\end{tabular}

Source: Elaborated by the authors.
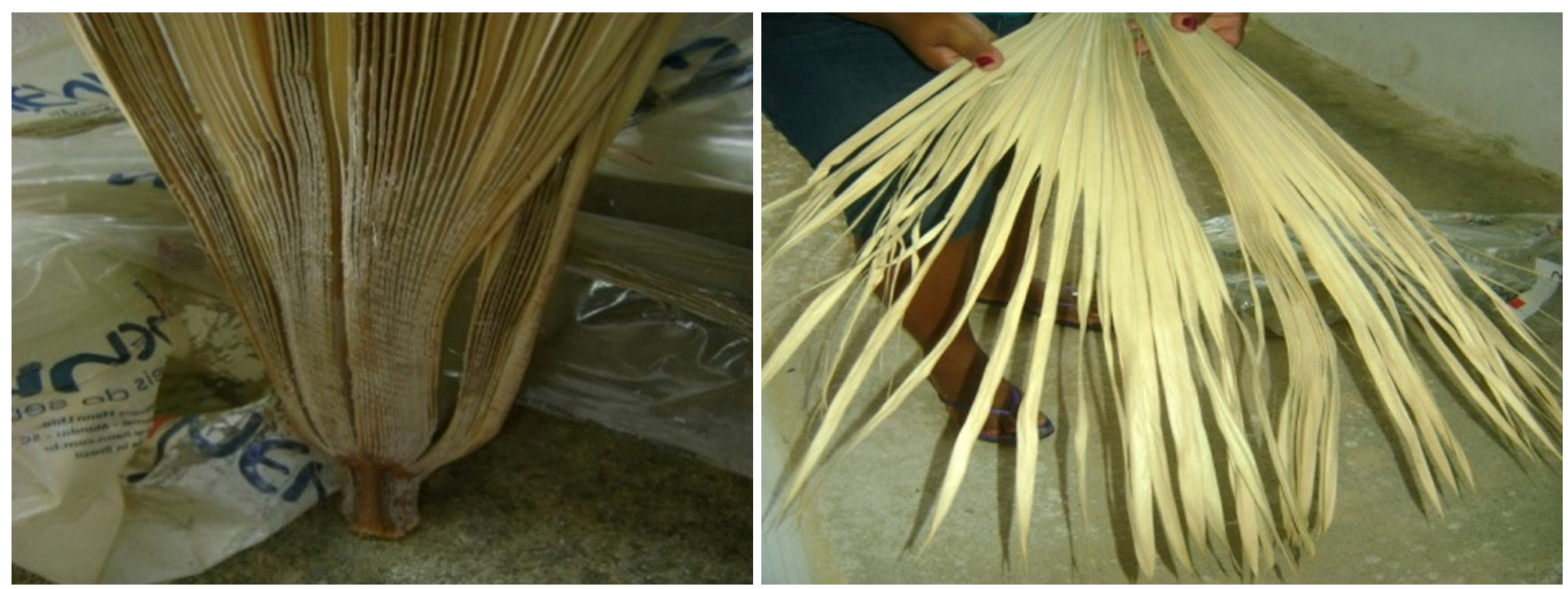

Figure 1. Carnauba straw. Source: Elaborated by the authors. the record book. Those who already know how to do crafts begin immediately; those who still do not know, are trained by the artisans of the association.

One of the main difficulties of the group is the rotation of members that is due to the dissatisfaction of the artisans who expect to receive on average a salary per month, a fact that is not due to the variability of sales volume. Those who still remain in the pool keep the work without and the artisan activity serves as income supplement. Another major difficulty is that the resistance of some customers to pay the price of products because they believe it should be cheaper because it is the countryside of the State. The main customer of ARTMAR is the ARTSOL Company and the main competitor is the Ceará handicrafts.

Each collaborator of the association is responsible for the entire process of materialization of the product. However, due to the distance from the association's headquarters to the homes of artisans, they work twice a week, in the morning and/or afternoon, and the other day at home, resulting in approximately $6 \mathrm{~h}$ per day. In addition to the recording of the amount of raw material that enters and exits, there is a quality control of the products, however, this is considered inefficient by artisans.

With a total of approximately 200 models (Figure 2) of carnauba straw products, the artisans are involved in the process of creation of the models, only in defining some parameters, such as dimensions, while the design is made by SEBRAE and is thus responsible for model creation.

The production of parts begins with the receipt of raw material, the fiber, which is placed to dry and then it is shredded and stored. Those that need to be dyed go to the process of dyeing and drying, for later preparation of the product; those used undyed, are directly taken to the confection. When there are remains of fibers, they are 
stored for later use. The finished product is then carried to the customer and marketed.

\subsection{Artisan group from Lajes Pintada}

The technique of the craft with the fiber of the sisal was brought to the municipality of Lajes Pintada, by the priest of Santa Cruz city, near the city, at a time when the plant was abundant in the region. At the end of 2000, the activity began to become organized. SEBRAE held a design course enabling the artisans of the region, enhancing their skills with the art of sisal, providing them with a better view of the market, and making the association official. Then there arose the AALP - Association of Lajes Pintada craftsmen - in early 2001.

The work of the craft with the sisal fiber is done by 12 women, in which, in addition to the crafts, the associated are also involved in the activities as homemakers and working in agriculture.

Each collaborator is responsible for the entire product realization process, from purchase to the end product. However, not all know how to do all kinds of the woven patterns. The work is not, mandatorily, held at the stipulated time it may vary according to the production made at home.

There are several types of manufactured parts (Figure 3), created mostly from the idea of a SEBRAE trainer.

The products of the Association have been selected for award in the SEBRAE TOP 100 Crafts, one of only two artisans' communities of this state in the ranking.

The market encompasses consumers and shopkeepers. There is no marketing strategy to capture this consumer market, everything happens casually through business relationships such as participation in round business sponsored by SEBRAE - and in the fairs.

The raw material sisal fibers (Figure 4), currently comes from João Câmara (RN). Upon receipt of the fiber, it is washed, laid to dry and stored. If the product needs dyeing, the fiber passes through the process of dyeing and drying. Then it is verified if there is need to use the loom (Figure 5) or manually fabricate the product. After produced, it is sent to the client and the existing leftovers are donated.

\subsection{Application of SCAMPER technique}

To perform the first stage of the dynamics initially sought to know which products had lower sales index with a member of each artisan group. Thus, the chosen products were: purse, Sousplat, coaster and the hat. After this stage, we constructed the auxiliary table (Table 4)

Compiling the possibilities of the auxiliary tables, we obtained the following SCAMPER Table for the products (Table 5).

Through the dynamic, some findings were reported. Primarily in Massaranduba, we analyzed that the material of the handbag's handle should be replaced due to the disturbance caused to customers. Soon after, the need to add value to it by combining the fabric of the same structure was verified, and the importance of the withdrawal of spare fiber in the outside of the handbag.

For Sousplat we realized the intention to reach other market, higher than the existing one, by changing the sales strategy. Moreover, the lacquer was also proposed to be combined with the original product and at the door beaker, taking into account the aesthetics and durability.
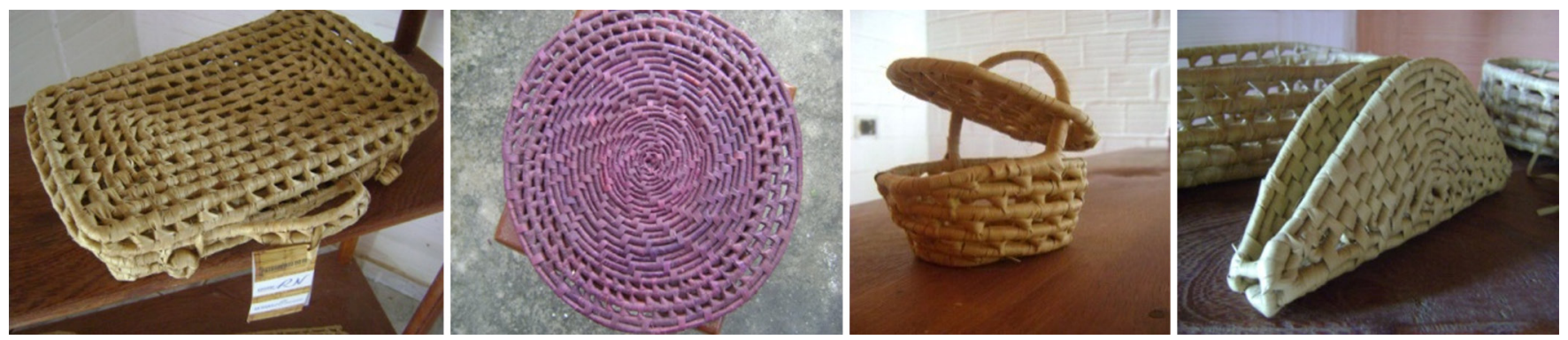

Figure 2. Products manufactured by the group of artisans from Massaranduba. Source: Elaborated by the authors.
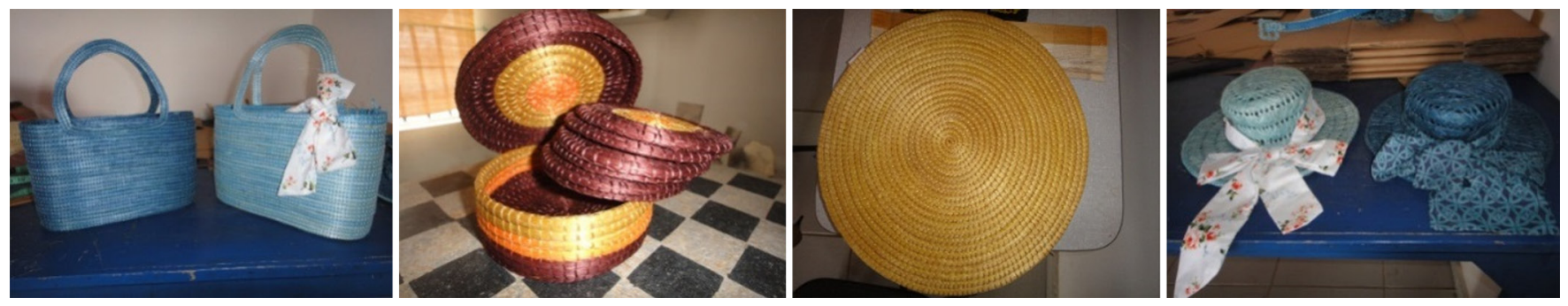

Figure 3. Products manufactured by the artisans of Lajes Pintada. Source: Elaborated by the authors. 
The SCAMPER table showed that the beverage coasters could be done in a variety of colors, even with the Brazilian flag - already aiming at 2014 World Cup -, it may have different formats, in addition to a package that expose it more and protect it, at the same time easy to be used as a part in the shape of "L".

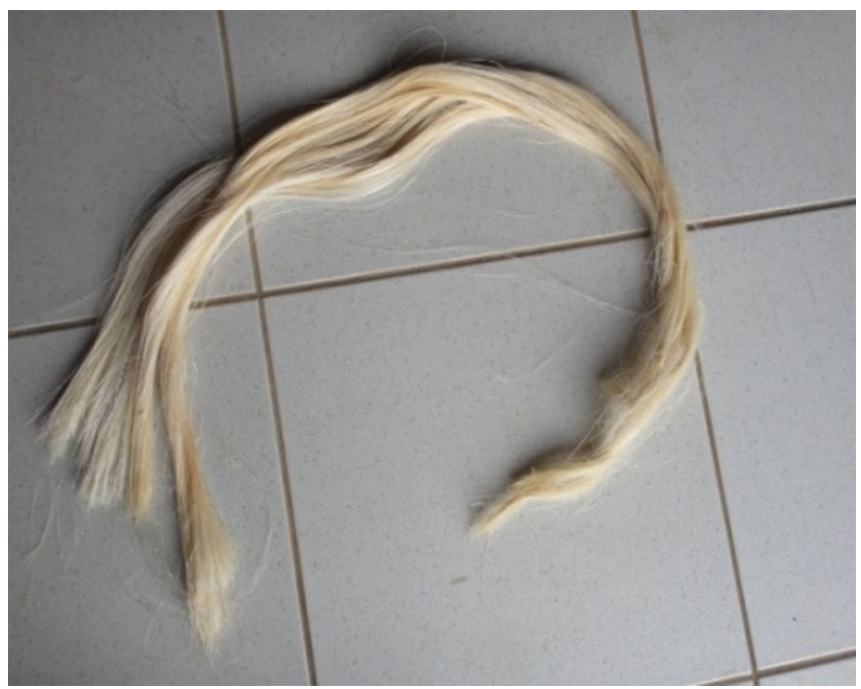

Figure 4. Sisal fiber. Source: Elaborated by the authors.

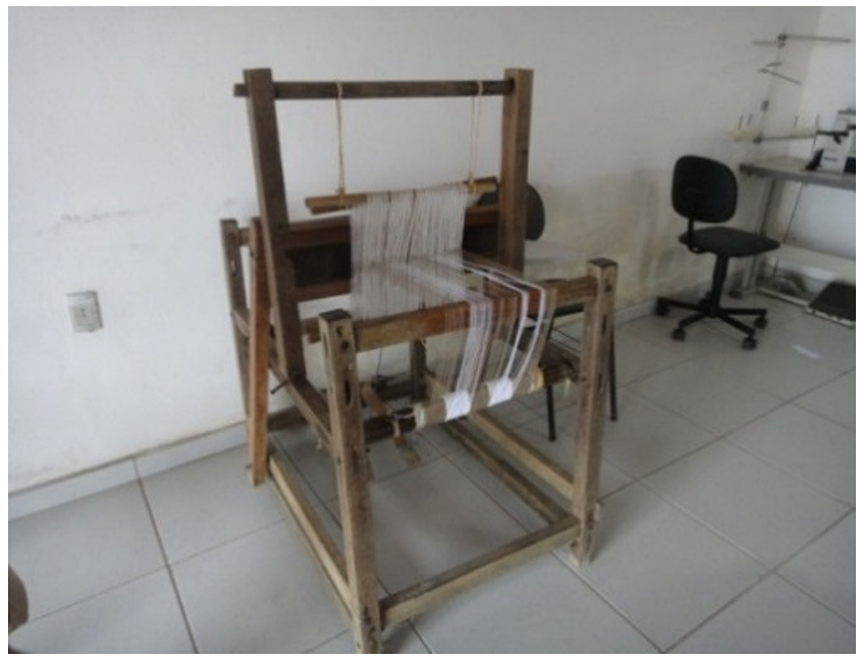

Figure 5. Loom machine. Source: Elaborated by the authors.
As for the community Lajes Pintada, we identified two products to be improved for the hat. The first would be a natural color visor - the most sought after, according to the artisans, as it represents best handmade products - and lining to avoid the discomfort caused by spare tips. The other would be a common beach hat, also in natural color, with a thicker fiber lining.

In addition, during the application of the technique, we suggested the creation of an identification tag of artisans group, as this would add value to the products to the extent that customers would be able to confirm that it was a handcrafted product and this would increase the likelihood of purchase.

\section{Results analyzes}

From the application of the dynamics in the communities we observed differences, both with regard to behavior and the attitude of the artisans. The SCAMPER is a practical tool that allowed the direction and organization for the development of dynamic, stimulating the generation of ideas, and enabling the creation of new versions of products that had a low sales index.

However, even with a simple tool, some aspects should be taken into consideration during the application so that it does not interfere negatively in the results. During interventions, we observed two problems. The first was related to the lack of standardization of production, which resulted in the disposal of possibilities when filling out the SCAMPER Table. The second refers to the little active members' participation of the artisans group. In addition to these specific factors, other comments were raised: the timidity of the artisans against the research group; the relationship between the involvement of each participant in the dynamic with their respective activity in the association, causing some artisans to fail to understand or do not "know" how should be involved, leaving it to the artisans who "ran" the group the task of driving dynamics; not familiar with the creativity topic and innovation, leading the artisans to consider as innovative product that which is no longer produced - or was never - by the association.

Table 4. Auxiliary table of the products from Massaranduba.

\begin{tabular}{|c|c|c|c|c|}
\hline Size & Braid & Colors & Shape & Utilization \\
\hline Small & Opened & Green & Round & Acessory \\
\hline Medium & Closed & Pinion & Square & Home Utility \\
\hline Large & & Oak & Rectangular & Decoration \\
\hline & & Walnut & Heart & \\
\hline & & Mahogany & Star & \\
\hline & & Red & Triangular & \\
\hline & & Orange & Oval & \\
\hline
\end{tabular}


Table 5. SCAMPER table of selected products.

\begin{tabular}{|c|c|c|c|c|c|}
\hline \multicolumn{3}{|c|}{ Group of Artisans from Massaranduba } & \multicolumn{2}{c|}{ Group of Artisans from Lajes Pintada } \\
\hline Stage & Handbag & Sousplat & Drink Coaster & Drink Coaster & Hat \\
\hline S - Sustitute & Strap material & Market class A & & Package & $\begin{array}{c}\text { Accessories, } \\
\text { Handbag }\end{array}$ \\
\hline C-Combine & Fabric coating & Varnish & Varnish & $\begin{array}{c}\text { Size, Sousplat with } \\
\text { coaster }\end{array}$ & \\
\hline A-Adapt & & & & Color, Shape, Size & $\begin{array}{c}\text { Color, Shape, Size, } \\
\text { point }\end{array}$ \\
\hline M- Modify & & & & Function & Decoration \\
\hline P- Purpose & & & Package & Curtain, Carpet, \\
\hline E - Eliminate & Fiber spare parts & & & Earring, Necklace \\
\hline R- Reverse & & & & \\
\hline
\end{tabular}

Source: Elaborated by the authors.

All these points raised, emphasize the importance of dynamic facilitator in both the implementation, as well as in conducting the participants, resulting in ideas of improving products of little creativity and other communities have already fabricated the same. This is because it is the facilitator who will work around these problems by inducing participants towards fulfilling the objective of the dynamic and assisting in dissuading aspects that act as a block in the progressing - like production capacity, that is, encouraging lateral thinking. Even so, the application of SCAMPER technique was effective because improvements were suggested for the products in both communities due to its systematic working.

\section{Final considerations}

The directing of creativity of an individual for innovative purposes is still something that needs to be studied in order to find an efficient way of doing this. Creativity and innovation have, among others, a subjective dimension, which makes the process more complex.

There are many variables that must be taken into consideration when proposing to convert creative ideas of an individual into an innovation. However, the main one is the target audience profile. Knowing the characteristics of the individuals is essential to choose the best way to work with creative potential; factors such as age, education, personality, make the same dynamic, applied in the same way in different groups, to have completely different results.

As a result, it was possible to observe that, in the application of dynamic described here, which mostly influenced the results, lack of affinity of participants with the divergent thinking, causing them to show a resistance to the generation of ideas. Thus, it is important that the facilitator will lead the momentum so that the participants are able to get on their scope of work to increase the degree of innovation of the proposed improvements.

Another aspect that must be presented to the participants is creativity like something more concrete, since this abstraction inherent in the concept also influences the inhibition of the creative potential of the participants, since they do not have much knowledge on the subject.

The fact that the applied dynamic doesn't require a lot of creative autonomy, made it possible to obtain satisfactory results with the generation of numerous ideas for improvement for the selected products, this way, the dynamic proved to be effective for this type of audience.

\section{References}

ALENCAR, E. A. Gerência da criatividade. São Paulo: Makron Books, 1996.

AMARAL, D. C.; ROZENFELD, H. Explicit knowledge management on the product development process. Product: Management \& Development, v. 1, p. 49-58, 2001.

BACCARELLI, R. M. O processo de Inovação. Economia \& Tecnologia, v. 2, p. 47-51, 1999.

BERGER, L. A.; SIKORA, M. J.; BERGER, D. R. The change management handbook: a road map to corporate transformation. New York: Irwin, 1995.

BISSOLA, R.; IMPERATORI, B. Organizing individual and collective creativity: flying in the face of creativity clichés. Creativity and Innovation Management, v. 20, n. 2 , p. $77-89,2011$. http://dx.doi.org/10.1111/j.14678691.2011.00597.x

BRENNAN, A.; DOOLEY, L. Networked creativity: a structured management framework for stimulating innovation. Technovation, v. 25, n. 12, p. 1388-1399, 2004. http://dx.doi.org/10.1016/j.technovation.2004.08.001.

BRUNO-FARIA, M. F. O caráter complexo do processo criativo em projetos inovadores. Revista de Administração Faces Journal, v. 6, p. 105-117, 2007.

BRUNO-FARIA, M. F.; VEIGA, H. M. S.; MACÊDO, L. F. Criatividade nas organizações: análise da produção científica nacional em periódicos e livros de Administração e Psicologia. Revista Psicologia Organizações e Trabalho, v. 8, p. 142-163, 2008. 
CHESBROUGH, H. W. Open services innovation: rethinking your business to grow and compete in a new era. San Francisco: Wiley, 2011.

CRESWELL, J. W. Projeto de Pesquisa: métodos qualitativo, quantitativo e misto. Porto Alegre: Artmed, 2010.

FAMILY, G. Collective creativity: a complex solution for the complex problem of the state of our planet. Creativity Research Journal, v. 15, n. 1, p. 83-90, 2003. http://dx.doi. org/10.1207/S15326934CRJ1501_9.

FISCHER, G. et al. Beyond binary choices: integrating individual and social creativity. International Journal of Human-Computer Studies, v. 63, n. 4-5, p. 482-512, 2005. http://dx.doi.org/10.1016/j.ijhcs.2005.04.014.

GONZÁLEZ, M. O. A. et al. Creative profile of undergraduate engineering in a Federal University. Product: Management \& Development, v. 12, n. 1, p. 49-54, 2014. http://dx.doi. org/10.4322/pmd.2014.006.

GONZÁLEZ, M. O; TOLEDO, J. C. A integração do cliente no processo de desenvolvimento de produto: revisão bibliográfica sistemática e temas para pesquisa. Revista Produção, v. 22, n. 1, p. 14-26, 2012.

GURTEEN, D. Knowledge, creativity and innovation. Journal of Knowledge Management, v. 2, n. 1, p. 5-13, 1988. http:// dx.doi.org/10.1108/13673279810800744.

ISAKSEN, S. G.; EKVALL, G. Managing for innovation: the two faces of tension in creative climates. Creativity and Innovation Management, v. 19, n. 2, p. 73-88, 2010. http:// dx.doi.org/10.1111/j.1467-8691.2010.00558.x.

MARTINS, E.; MARTINS, N. An organizational culture model to promote creativity and innovation. Journal of Individual Psychology, v. 28, p. 58-65, 2002.

MIGUEL, P. A. C. Metodologia de pesquisa em engenharia de produção e operações. Rio de Janeiro: Elsevier, 2010.

NAKAKOJI, K.; OHIRA, M.; YAMAMOTO, Y. Computational support for collective creativity, knowledge-based systems. Knowledge-Based Systems, v. 13, n. 7-8, p. 451-458, 2000.
OSTROWER, F. Criatividade e processos de criação. Petrópolis: Vozes, 1999.

PAGE, A. L.; SCHIRR, G. R. Growth and development of a body of knowledge: 16 years of new product development research, 1989-2004. Journal of Product Innovation Management, v. 25, n. 3, p. 233-248, 2008. http://dx.doi. org/10.1111/j.1540-5885.2008.00297.x.

ROFFE, I. Innovation and creativity in organizations: a review of the implications for training and development. Journal of European Industrial Training, v. 23, n. 4-5, p. 224-237, 1999. http://dx.doi.org/10.1108/03090599910272103.

RUNCO, A. M. Creativity, theories and themes: research, development, and practice. San Diego: Elsevier, 2007.

SILVA, A.; HENRIQUES, E.; CARVALHO, A. Creativity enhancement in a product development course through entrepreneurship learning and intellectual property awareness. European Journal of Engineering Education, v. 34, n. 1, p. 63-75, 2009. http://dx.doi. org/10.1080/03043790802710201.

SMITH, G. F. Idea-generation techniques: a formulary of active ingredients. The Journal of Creative Behavior, v. 32, n. 2, p. 107-133, 1998. http://dx.doi.org/10.1002/j.2162-6057.1998. tb00810.x.

SOUZA, I. F.; SOARES, A. C. C. A importância da criatividade para a produtividade e qualidade do trabalho. Revista Eletrônica Lato Sensu, v. 3, p. 1-13, 2007.

VAN EIJNATTEN, F. M. V.; SIMONSE, L. W. L. Organizing for creativity, quality and speed in product creation processes. Quality and Reliability Engineering International, v. 15, n. 6, p. 411-416, 1999. http://dx.doi. org/10.1002/(SICI)1099-1638(199911/12)15:6<411::AIDQRE297>3.0.CO;2-G.

YIN, R. Estudo de caso: planejamento e métodos. Porto Alegre: Bookman, 2001. 